\title{
GP1BA wt Allele
}

National Cancer Institute

\section{Source}

National Cancer Institute. GP1BA wt Allele. NCI Thesaurus. Code C126547.

Human GP1BA wild-type allele is located in the vicinity of $17 \mathrm{p} 13.2$ and is approximately 3 $\mathrm{kb}$ in length. This allele, which encodes platelet glycoprotein Ib alpha chain protein, is involved in the regulation of blood coagulation. Mutation of the gene is associated with Bernard-Soulier syndrome type A1 and platelet-type von Willebrand disease and with increased susceptibility to nonarteritic anterior ischemic optic neuropathy. 